

\section{Daftar Isi (Table of Content) Journal of Government
Civil Society}

\begin{tabular}{|c|c|}
\hline \multirow{3}{*}{$1-30$} & $\begin{array}{l}\text { The Application of Social Movement as a Form of Digital Advocacy: Case of } \\
\text { \#TolakRUUPermusikan }\end{array}$ \\
\hline & Muhammad Ananda Alifiarry ${ }^{1}$, Bevaola Kusumasari ${ }^{1}$ \\
\hline & $\begin{array}{l}\left({ }^{1} \text { Department of Public Policy and Management, Faculty of Social and Political Sciences, }\right. \\
\text { Universitas Gadjah Mada, Indonesia) }\end{array}$ \\
\hline \multirow{3}{*}{$31-50$} & $\begin{array}{l}\text { Urban Resilience Strategy in the Climate Change Governance in Makassar } \\
\text { City, Indonesia }\end{array}$ \\
\hline & $\begin{array}{l}\text { Ihyani Malik }{ }^{1} \text {, Andi Luhur Prianto }{ }^{2} \text {, Abdillah Abdillah², Zaldi Rusnaedy }{ }^{3} \text {, } \\
\text { Andi Annisa Amalia }{ }^{4}\end{array}$ \\
\hline & $\begin{array}{l}\text { (' Department of Public Administration, Universitas Muhammadiyah Makassar, Indonesia) } \\
\text { (' Department of Government Studies, Universitas Muhammadiyah Makassar, Indonesia) } \\
\text { ( }{ }^{3} \text { Department of Government Studies, Universitas Pancasakti Makassar, Indonesia) } \\
\text { ( }{ }^{4} \text { Department of Architecture, Faculty of Engineering, Universitas Muhammadiyah } \\
\text { Makassar, Indonesia) }\end{array}$ \\
\hline \multirow{3}{*}{$51-62$} & $\begin{array}{l}\text { Collaboration Governance in The Development of Natural Based Tourism } \\
\text { Destinations }\end{array}$ \\
\hline & 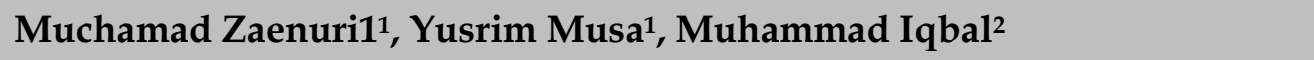 \\
\hline & $\begin{array}{l}\text { (1 Department of Government Affairs and Administration Universitas Muhammadiyah } \\
\text { Yogyakarta, Indonesia) } \\
\text { (2 Department of Political Science National Cheng Kung University, Taiwan, Province of } \\
\text { China) }\end{array}$ \\
\hline \multirow{3}{*}{$63-78$} & $\begin{array}{l}\text { Analysis of Mind Patterns and Work Culture in Government of West } \\
\text { Pasaman District }\end{array}$ \\
\hline & $\begin{array}{l}\text { Sri Andri Yani1 }{ }^{1} \text {, Etika Khairina1, Suswanta1, Mochammad Iqbal } \\
\text { Fadhlurrohman' }\end{array}$ \\
\hline & (1 Governmental Studies, Universitas Muhammadiyah Yogyakarta, Indonesia) \\
\hline \multirow{2}{*}{$79-90$} & $\begin{array}{l}\text { The Influence of Social Media (Instagram) of Bantul's General Election } \\
\text { Commissions on Voters Participation in the } 2019 \text { Elections }\end{array}$ \\
\hline & $\begin{array}{l}\text { Agus Priyanto', Eko Priyo Purnomo }{ }^{1,2} \text {, Mochammad Iqbal } \\
\text { Fadhlurrohman }^{1} \text {, Herry Fahamsyah", Etika Khairina }\end{array}$ \\
\hline
\end{tabular}


(1 Departement of Government Affairs and Administration, Universitas Muhammadiyah Yogyakarta, Indonesia)

(2 Jusuf Kalla School of Government, Universitas Muhammadiyah Yogyakarta, Indonesia)

Model Implementation Trap of Policy New Student Acceptance Zoning System in Makassar City

91 - 106 Nuryanti Mustari' ${ }^{1}$, Rudi Hardi ${ }^{1}$, Amir Muhiddin ${ }^{1}$

( ${ }^{1}$ Department of Government Studies, Faculty of Social and Political Sciences, Universitas Muhammadiyah Makassar, Indonesia)

Collaborative Urban Governance Model in Environmental Management of Industrial Area

Tri Sulistyaningsih"1, Saiman', Nofianda Fatimah Azzahra1, Nanda

$107-126$ Adityawan'2, Mohammad Jafar Loilatu ${ }^{3}$

( ${ }^{1}$ Department of Government Studies, Universitas Muhammadiyah Malang Indonesia) (2 Civil Engineering, Sepuluh Nopember Institute of Technology, Surabaya, Indonesia) ( ${ }^{3}$ Government Affairs and Administration, Universitas Muhammadiyah Yogyakarta, Indonesia)

Towards an Integration of Immigration and Customs Agency in Indonesia: A Step-by-Step Process

\section{7 - $144 \quad$ Ridwan Arifin' ${ }^{1}$, Intan Nurkumalawati ${ }^{1}$}

(1 Diploma Program of Immigration Administration, Polytechnic of Immigration, Indonesia) 


\title{
The Influence of Social Media (Instagram) of Bantul's General Election Commissions on Voters Participation in The 2019 Elections
}

\author{
Agus Priyanto ${ }^{1}$, Eko Priyo Purnomo ${ }^{1,2^{*}}$, Mochammad Iqbal Fadhlurrohman ${ }^{1}$, Herry \\ Fahamsyah $^{1}$, Etika Khairina ${ }^{1}$ \\ ${ }^{1}$ Departement of Government Affairs and Administration, Universitas Muhammadiyah Yogyakarta, \\ Indonesia \\ ${ }^{2}$ Jusuf Kalla School of Government, Universitas Muhammadiyah Yogyakarta, Indonesia \\ *Email Correspondence: eko@umy.ac.id
}

\begin{abstract}
In 2019 social media has indeed become a familiar phenomenon for Indonesian people in general. Social media is a communication tool that cannot be abandoned by every individual. In fact, it has become a habit for every individual to share information through social media, because the practical benefits of social media are a means of communication. Social media in its use has many benefits, both positive and negative, like two ends of the sword. The positive value of social media is used as a means of communication, a means of sharing information for voters, and a means of socializing between the KPU and the public. This study uses a qualitative descriptive method by describing the data obtained from the General Election Commission (KPU) of Bantul Regency by analyzing data taken directly from the documents of the General Election Commission of Bantul Regency (KPU Bantul). Voter Participation in Bantul Regency shows a higher participation rate compared to participation in the 2014 Election. The difference between the 2014 and 2019 Elections lies in the number of voters. In 2014 Facebook was used while in 2019 it was using Instagram. The percentage of voter participation in 2019 showed 87.9\% of the total number of voters, while in 2014 voter participation was only 81\% (Republika.co.id). In the 2014 Election, the KPU did not use Instagram to disseminate information about the Election, while the 2019 Election showed good participation.
\end{abstract}

Keywords: Participation, Social Media, Election

\begin{abstract}
ABSTRAK
Di tahun 2019 media sosial memang menjadi fenomena yang tidak asing lagi bagi masyarakat Indonesia pada umumnya. Media sosial merupakan alat komunikasi yang tidak bisa ditinggalkan oleh setiap individu. Bahkan sudah menjadi kebiasaan setiap individu untuk berbagi informasi melalui media sosial, karena manfaat praktis media sosial adalah sebagai sarana komunikasi.Media sosial dalam penggunaannya memiliki banyak manfaat, baik positif maupun negatif, ibarat dua ujung pedang. Nilai positif media sosial digunakan sebagai sarana komunikasi, sarana berbagi informasi bagi pemilih, dan sarana sosialisasi antara KPU dengan masyarakat.Penelitian ini menggunakan metode deskriptif kualitatif dengan mendeskripsikan data yang diperoleh dari dokumen Komisi Pemilihan Umum (KPU) Kabupaten Bantul dengan menganalisis data yang diambil langsung dari dokumen Komisi Pemilihan Umum Kabupaten Bantul (KPU Bantul). Partisipasi Pemilih di Kabupaten Bantul menunjukkan angka partisipasi yang lebih tinggi dibandingkan dengan partisipasi pada Pemilu 2014. Perbedaan Pemilu 2014 dan 2019 terletak pada jumlah pemilih. Pada tahun 2014 Facebook digunakan sedangkan pada tahun 2019 menggunakan Instagram. Persentase partisipasi pemilih pada 2019 menunjukkan 87,9\% dari total jumlah pemilih, sedangkan pada 2014 partisipasi pemilih hanya 81\% (Republika.co.id).
\end{abstract}

Citation : Priyanto, A., Purnomo, E. P., Fadhlurrohman, M. I., Fahamsyah, H., \& Khairina, E. (2021). The Influence of Social Media (Instagram) of Bantul's General Election Commissions on Voters Participation in the 2019 Elections. Journal of Government and Civil Society, 5(1), 79-90. 
Pada Pemilu 2014, KPU tidak menggunakan Instagram untuk menyebarluaskan informasi seputar Pemilu, sedangkan Pemilu 2019 menunjukkan partisipasi yang baik.

Kata kunci: Partisipasi, Media Sosial, Pemilihan

\section{INTRODUCTION}

In 2019 social media has become a phenomenon that is not new to Indonesian people in general. Social media is a communication tool that cannot be abandoned by every individual (Rahmat \& Purnomo, 2020). In fact, it has become a habit for every individual to share information through social media, because the practical benefits of social media are a means of communication (Rohim\&Wardana, 2019). What's more, unfortunately social media also has some side effects. It is not only a habit but a new culture that replaces the existing culture(Yunus, 2015). Social media changes culture across age groups from children to the elderly, although not all children use social media where children, especially ages 8-12, are still low in social media use (Cahyono, 2016; Efendi, Astuti, \& Rahayu, 2017). Cultural changes such as face-to-face communication, which is now without faceto-face communication, are commonplace in society (Rachmandani, Purnomo, \& Kasiwi, 2020). Nowadays space is no longer needed to communicate and time is also not a barrier to communication. Those are some of the benefits of social media as a means of communication between individuals, between groups and other groups (Munandar \& Suherman, 2016).

Communication with social media has changed culture, especially face-to-face communication. However, with today's social media, communication does not have to be face-to-face, now someone who has a handheld device (cellphone / smartphone) can communicate easily (Errika, 2015; Putri, Nurwati, \& S., 2016) Social media in terms of its use are communication tools, socialization tools, information tools. In the history of elections in Indonesia, social media has not been widely used in socializing elections in previous elections (before 2019) even though elections have been held eleven times since 1955, 1971, 1977, 1982, 1987, 1992, 1997, 1999, 2004, 2009 and 2014 Only in the 2019 Election, social media emerged and played an active role in the socialization of the Election (Fadhlurrohman \& Purnomo, 2020). No exception, the Bantul General Election Commission (KPU) Instagram was also used to disseminate this information (Rachmandani et al., 2020; Rohim \& Wardana, 2019). Social media in the 2019 Election has had a very strong influence on voters, especially young or millennial voters. Social media can be used in various ways, one of which is the dissemination of positive or negative information, it all depends on the social media users themselves. The number of novice or young voters reaches 14 million, of whom are active users of social media (Husna \& Novita, 2019). 
Social media in its use has many benefits, both positive and negative, like two ends of the sword. The positive value of social media is used as a means of communication, a means of sharing information for voters, and a means of socializing between the KPU and the public (Susanto, 2017). On the other hand, the negative value of social media is spreading irresponsible information or hoaxes (Faraidiany, Kusmanto, \& Warjio, 2019). Social media has had a tremendous influence when social media, especially Instagram, the Bantul General Election Commission (KPU Bantul) is used to share the latest information related to the general election. From this Instagram account, voters can see and use this information as a reference for selecting candidates in the 2019 Election held by the KPU Bantul (Michela Arnaboldi, 2016). Furthermore, social media is a tool for disseminating election information including election procedures (Strandberg, 2013). Socialization through Instagram social media is one way for the Bantul Regency Election Commission to see great opportunities from first-time voters to non-novice voters (Juwandi, Nurwahid, Lestari, Sultan, \& Tirtayasa, 2019). Social media has a tremendous influence on social media users from the lifestyle that follows social media. From there, social media was put to good use by the Bantul KPU in disseminating information related to the 2019 General Election in Bantul to increase voter participation in particular (Hidayat, Basith, \& Faqih, 2018).

Using a social media platform like Instagram by uploading images on the platform will reach all Instagram users (Aisyah, Fadilah, \& Sjafirah, 2020; Susanto, 2017). In addition to uploading images, Instagram can be used to share various information and can be used as a communication tool through its functions (Rahadi, 2017). Besides having the function of Instagram as Direct Messenger, there are also hashtags, locations, follow, share, like, comments (Setyaningsih, Suadnya, \& Fajarica, 2020); First, Hashtag is tagging by placing the hashtag symbol '\#' right before the word to be tagged. Hashtags are like keywords that link posts with the same hashtag (Setiawan \& Santoso, 2013). This will make it easier for users to find information about the same keyword / topic / hashtag. Second, Location is a feature on Instagram that is used to show the location of the Instagram user or where the post was posted(Panjaitan \& Prasetya, 2017). Third, Follow is a feature that shows someone wants to follow us, or a certain channel, picture, profile, and vice versa. Fourth, Sharing is a feature for sharing to social media other than Instagram. Fifth, Like is a feature to show that the user likes the post. Sixth, Comments are features for commenting. Users can comment and reply to other users' comments to enrich the discussion.

In addition, for beginner voters who can be said to be unfamiliar with political issues, because they are very close to social media, social media in politics can be used as a reference for political nets and as a determining material for which candidates they will choose (Juwandi et al., 2019). Indeed, young voters who are often called millennials have a considerable influence on the 2019 Election (Agustin, 2019). Young voters, or novice or 
novice voters, according to the Election Law Number 10 of 2008 Article 19 Paragraph (1) are Indonesian citizens who old age. 17 (seventeen) years or more. Beginner voters are voters who are participating in the election for the first time, aged at least 17 years or not yet 17 years old but have a family (Tassel, J. Van, \& Poe-Howfield, 2010).

With the many benefits of social media being used as a means of communication without any limitations in space and time in its use, social media can be a tool for conducting campaigns and political socialization both positively and negatively(Soliha, 2015). Based on these reasons, the researcher aims to examine the social media used by the General Election Commission (KPU) of Bantul Regency. The research will look at whether Instagram specifically affects voter participation in the 2019 Pilkada in Bantul Regency, where Instagram is used by the Bantul KPU in disseminating information about the 2019 simultaneous elections(Moleong, 2013). This research uses a qualitative descriptive method by describing the data obtained from the General Election Commission documents (KPU) of Bantul Regency by analyzing data taken directly from the documents of the General Election Commission of Bantul Regency (KPU Bantul). In addition, researchers also conducted interviews with Bantul KPU ranks. Then the data from the Instagram of the Bantul KPU were analyzed using Nvivo 12 plus Ncapture with data from the KPU. Meanwhile, specific data on KPU socialization can be seen from posts on Instagram from January 1, 2019 to April 17,2019.

\section{FINDINGS AND DISCUSSION}

The researchers use a framework illustrated in the following figure, in addition to a theory where social media is used as a communication tool, information tool, and socialization tool (Susanto, 2017)). The KPU of Bantul uses social media (Instagram) as a means of socialization to voters, so that it will see Instagram's influence on general voter participation in 2019.
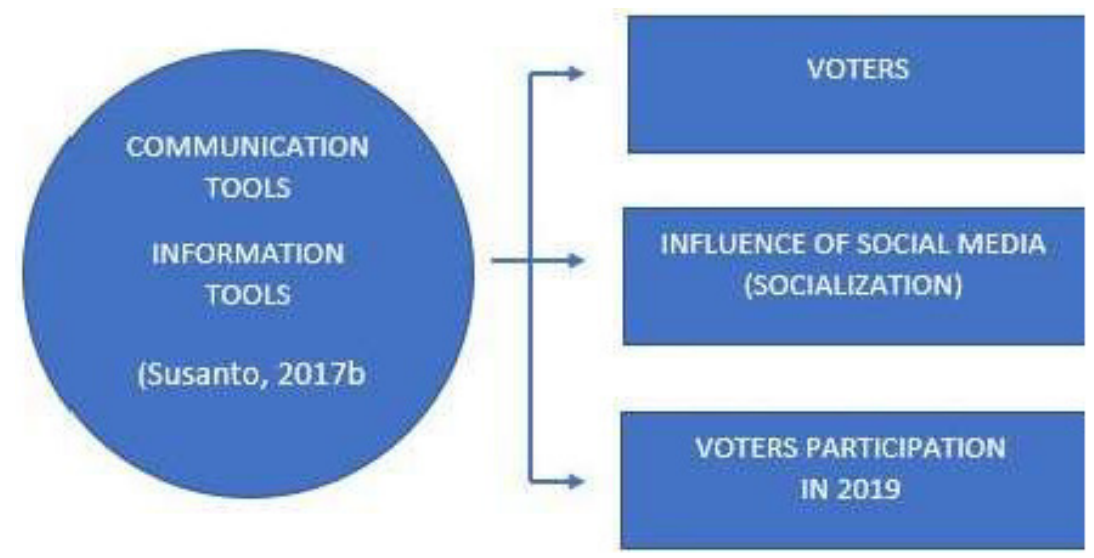

Figure 1. Research Concept Framework 
1. Communication tools. From the perspective of social media as a communication tool, social media is used for the communication of the Bantul's Election Commissions with the voters in the 2019 Elections to influence the voter participation in Bantul Regency.

2. Information tools. As an information tool, social media is used to share information of the General Elections Commission with the voters in the 2019 elections so that it affects the voters' participation in Bantul Regency.

3. Socialization tool. This perspective will see whether social media is used by the Election Commissions to disseminate information about the 2019 General Elections in Bantul Regency.

\section{Information on The Social Media of the Bantul's KPU (Instagram)}

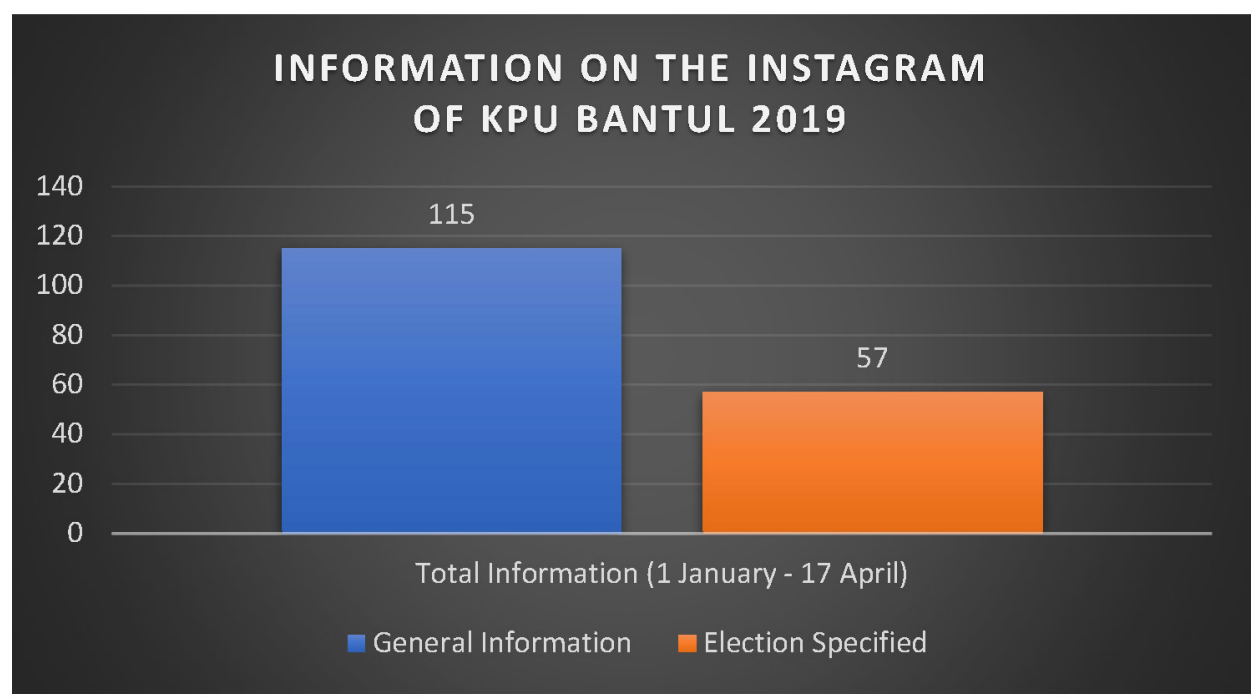

Figure 2. Comparison of the Information (KPU Bantul's Instagram) Source: KPU Bantul's Instagram

The researchers obtained data from the social media Instagram of Bantul's General Election Commissionsin the forms of information provided, in accordance with the benefits of social media as a communication tool, as an information tool and socialization tool from the social media owners to their followers in the social media (Susanto, 2017). The researchers view the information on social media Instagram of Bantul's General Election Commissionsseparately, where information is divided into two, namely general information and the information specifically containing information about the General Elections, which is categorized as election information,or in other words, the information that shows the socialization of 2019 General Elections. Furthermore, the researchers calculated manually from January 1, 2019, until the election day or April 17, 2019 to get the data as presented 
in the figure above. In total, the total of information submitted on Instagram was as much as 115 for a period of January 1, 2019 to April 17, 2019. As much as 58 of all posts from the period are about general information and the rest 57 posts show information or socialization related to the General Elections. The data on the social media Instagram of the Bantul's General Election Commissionscapturesits seriousness in carrying out the socialization of 2019 General Electionsthrough social media. This seriousness is based on the numbers of information disseminated, especially related to the socialization of the General Elections, with a $50 \%$ figure. The effort is expected to affect the value of voter participation in the 2019 General Elections in Bantul Regency related to the election of the Regional House of Representatives level 1 or 2 and the House of Representatives at the national level and the election of President and Vice President in 2019.

\section{Numbers of Voters in Bantul Regency}

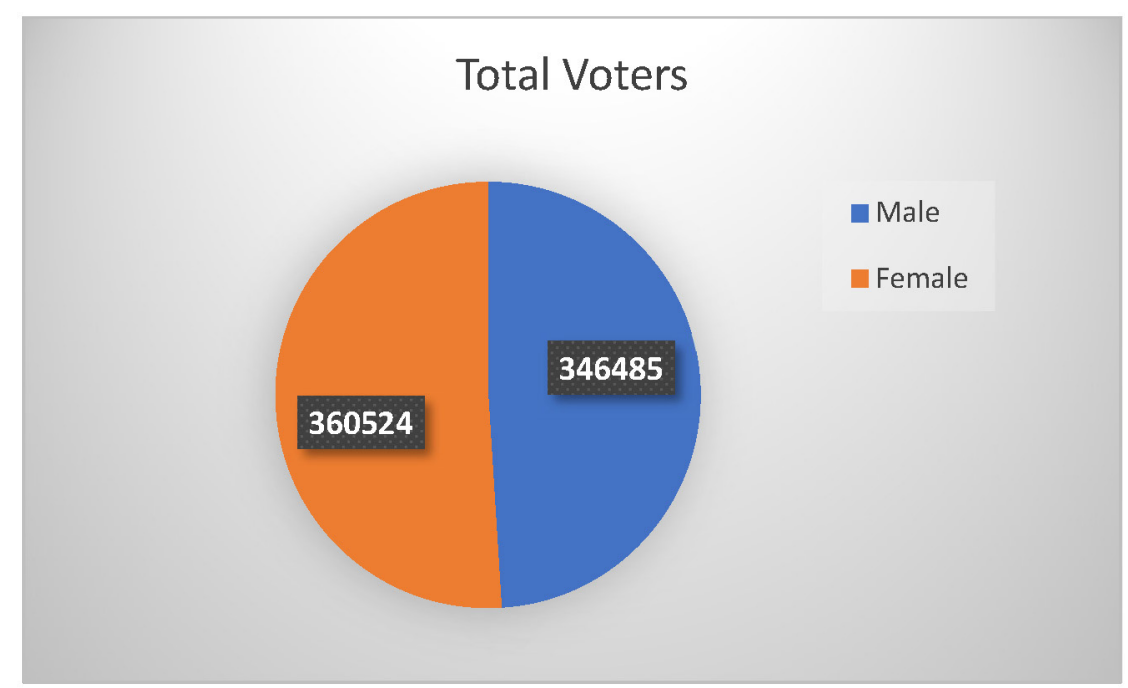

Figure 3. Numbers of Voters (document of the KPU of Bantul) Source: KPU Bantul's Document

The data ofvoters were obtained from General Election Commissions of Bantul Regency in the 2019 election year. Overall,there were 707,009 voters registered in the 2019 General Elections in Bantul Regency. Specifically, there were 346,485 male voters and 360,524 female voters. The numbers of female voters are indeed greater as the percentage of male voters was $49 \%$ while the female one was $51 \%$. More precisely, there were 14,039 female voters more than male voters in the 2019 General Elections in Bantul Regency. 
The voters in 2019 General Elections in Bantul Regency were classified further from men and women into novice voters, disabled voters, and non-disabled non-voter voters. The data shows that non-disabled non-novice voters showed a high number compared to novice voters and voters with disabilities with the total voters of 653,776 (92.41\%) voters. The numbers of non-novice voters and non-disabled voters showed a very drastic value compared to novice voters and voters with disabilities because thetotal of the voters was above $90 \%$, which is the dominant voterswith all respectcompared to first-time voters and disabled voters.

Furthermore, novice voters occupy the second rank after non-novice voters and nondisabled voters, with the total of novice voters of 53,233 (7.42\%) voters. The number of novice voters was not too significant compared to overall voters in Bantul Regency, yet the Bantul Regency General Elections Commissionshad a special focus on handling novice voters. This is shown from its Instagram account which really showed special attention to the novice voters for instance by giving socialization of 2019 Elections with a case of the formation of 'volunteers of democracy' for the General Elections Commissions of Bantul Regency. This particularly shows how serious the Commissions seeks and promotes the importance of participation in the 2019 General Elections, as to increase the numbers of novice voter participation and overall voter participation in general including the voters with a disability.

Meanwhile, the voters with disabilitieswere as much as $1960(0.27 \%)$ voters in Bantul Regency in the 2019 General Elections. Moreover, this number was categorizedinto the types of disabilities: 435 physically disabled voters, 350 blind voters, 377 deaf voters, 413 voters with mental disabilities, and 385 voters with other disabilities. The documents of the Bantul Regency Election Commissions showed that voters in Imogiridistrict had the most voters with disabilities with 180 voters while the least from Pundongdistrict with 58 voters. 


\section{Voters Participation in Bantul Regency}

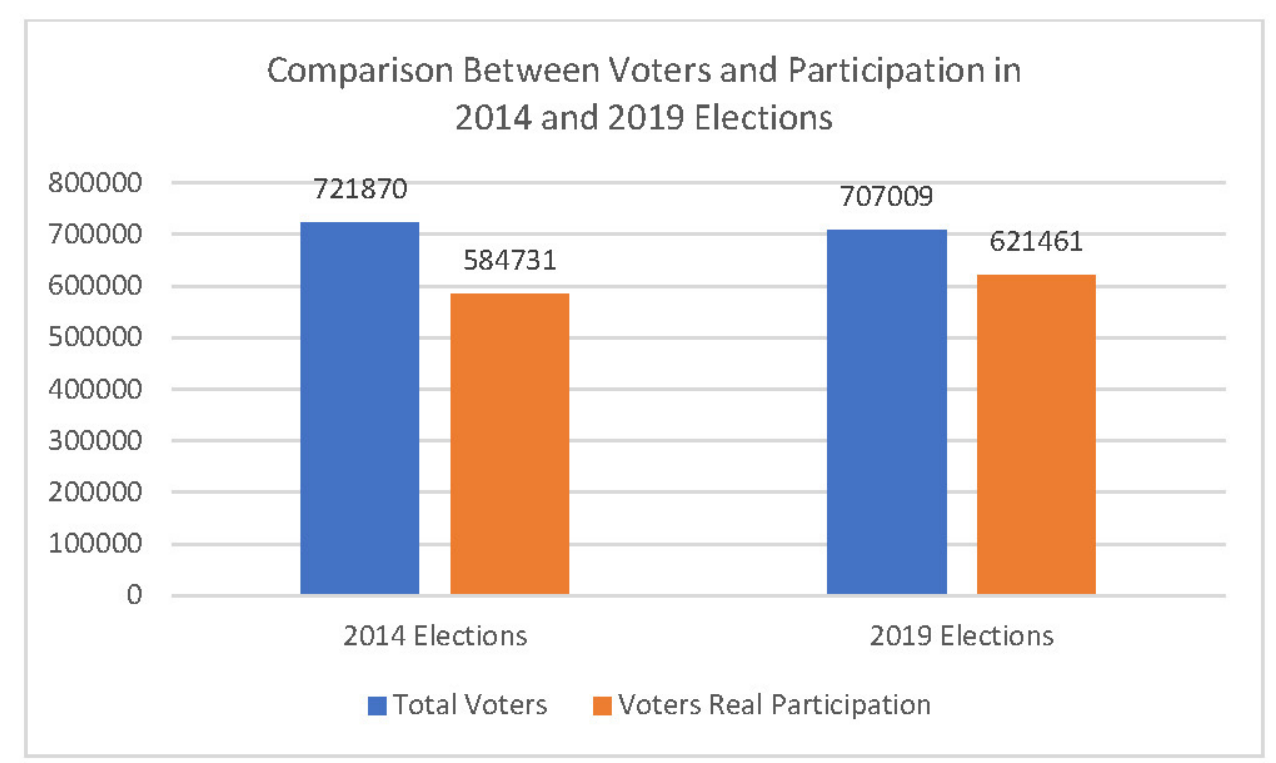

Figure 4. Table of Voter Participation in Bantul Regency Source: KPU Bantul 2019(Document)

The General Elections in 2019 shows a higher number of participation compared to the participation in the 2014 General Elections. In the 2014 General Elections with a total number of voters that is as much as 721,871 voters was actually greater than the 2019 General Elections, yet the participation in the election was only 81\% (584,731 voters). Meanwhile,the 2019 Elections with 707,009 voters had a greater participation value of $87.9 \%$ (621,461 voters). The number of participation from both the 2014 and 2019 General Elections shows different voting participation in Bantul Regency. Indeed, the General Elections Commissions of Bantul Regency in 2014 had not yet used socialization through Instagram whereas in 2019 Bantul Regency General Elections Commission used Instagram as a socialization tool. The difference between the 2014 General Elections and the 2019 General Elections is the use of Instagram as a tool for socialization by the Bantul Regency Election Commissions.

In 2014, the General Elections Commission of Bantul Regency used Facebook social media as a means of socializing General Elections. "The difference between the 2019 and 2014 General Elections lies in addition to the number of voters. Another difference is the socialization tool of the General Elections Commission of Bantul, namely Facebook and Instagram. In 2014 Facebook is used while in 2019 was Instagram," said the respondent. 
The researchers in this study want to see the influence or role of social media, especially Instagram, usedas the socialization tool of the Bantul's General Election Commissions in the success of the Elections related tovoter participation in the 2019 General Elections. The percentage of voter participation in 2019 shows $87.9 \%$ out of the total voter numbers, while in the 2014 General Elections the voter participation was only 81\% (Republika.co.id, 2014). In the 2014 General Elections, the Commissions did not use Instagram in disseminating information aboutGeneral Elections, while the 2019 General Elections which utilized the social media Instagram demonstrated good participation, showing an increase of $6.9 \%$.

The finding reflectsthe benefits of social media as a communication tool and as an information tool so that a user could interact with each other sharing information. Besides, social media is a means of socialization that is connecting one user to another (Susanto, 2017b). With this regard, the researchers confirm what Susanto said, where social media, especially Instagram, is a communication tool, an information tool, and a socialization tool.

\section{CONCLUSION}

Social media is used as a communication tool, information tool, and socialization tool. KPU Bantul uses social media (Instagram) as a means of socializing to voters. Researchers calculated manually starting January 1, 2019 until election day or April 17, 1919 to get the data. Data on the KPU's Instagram social media captures its seriousness in disseminating the 2019 Election through social media. This seriousness was based on the large amount of information disseminated, especially related to election socialization, with a figure of $50 \%$. These efforts are expected to affect the value of voter participation.

Voter data was obtained from the Bantul Regency KPU in the 2019 election year. Overall, there were 707, 009 voters who registered in the 2019 Election. The number of non-beginner voters without disabilities showed a high number compared to first-time voters and voters with disabilities with a voter turnout of 653,776 (92.41\%). The number of first-time voters is not too significant compared to the overall voters, but the Bantula KPU has a special focus on dealing with first-time voters.

Voter Participation in Bantul Regency shows a higher participation rate compared to participation in the 2014 Election. The difference between the 2014 and 2019 Elections lies beside the number of voters. In 2014 Facebook was used while in 2019 it was Instagram. The percentage of voter participation in 2019 showed $87.9 \%$ of the total number of voters, while in 2014 voter participation was only 81\% (Republika.co.id). In the 2014 Election, the KPU did not use Instagram to disseminate information about the Election, while the 2019 Election showed good participation. 


\section{REFERENCES}

Agustin, T. (2019). Hubungan Media Sosial dan Ketokohan Capres - Cawapres Terhadap Perilaku Pemilih Pemula di Kabupaten Gresik Pada Pilpres 2019. Sustainability (Switzerland), 11(1), 1-14. Retrieved from http://scioteca.caf.com/bitstream/handle/ 123456789/1091/RED2017-Eng 8ene.pdf?sequence=12\&isAllowed=y\%0Ahttp:/ / dx.doi.org/10.1016/j.regsciurbeco.2008.06.005\%0Ahttps:/ / www.researchgate.net/ publication/305320484_Sistem_Pembetungan_Terpusat_Strategi_Melestari

Aisyah, R. N., Fadilah, E., \& Sjafirah, N. A. (2020). Penggunaan Infografis pada Akun Instagramtirtoid sebagai Strategi Cross-media. Jurnal Kajian Jurnalisme, 3(2), 210. https:/ / doi.org/10.24198/jkj.v3i2.22276

Cahyono, A. S. (2016). Pengaruh media sosial terhadap perubahan sosial masyarakat di Indonesia. Jurnal Ilmu Sosial \& Ilmu Politik Diterbitkan Oleh Fakultas Ilmu Sosial \& Politik, Universitas Tulungagung, 9(1), 140-157. Retrieved from http://www.jurnal-unita.org/ index.php/publiciana/article/download/79/73

Efendi, A., Astuti, P. I., \& Rahayu, N. T. (2017). Analisis Pengaruh Penggunaan Media Baru Terhadap Pola Interaksi Sosial Anak Di Kabupaten Sukoharjo. Jurnal Penelitian Humaniora, 18(2), 12. https:// doi.org/10.23917/humaniora.v18i2.5188

Errika, W. S. D. (2015). Membaca Kearifan Lokal Dalam Penggunaan Media Sosial. Jurnal Transformatika, 13(1), 20-23.

Fadhlurrohman, M. I., \& Purnomo, E. P. (2020). The role of online mass media as a tool for the 2019 political campaign in Indonesia. Jurnal Studi Komunikasi (Indonesian Journal of Communications Studies), 4(2), 311. https://doi.org/10.25139/jsk.v4i2.2182

Faraidiany, M., Kusmanto, H., \& Warjio, W. (2019). Politik Identitas dalam Iklan Politik pada Pemilihan Kepala Daerah Sumatera Utara 2018. Jupiis: Jurnal Pendidikan IlmuIlmu Sosial, 11(1), 113. https:// doi.org/10.24114/jupiis.v11i1.12310

Hidayat, D. R., Basith, A. A., \& Faqih, M. Z. Al. (2018). Literasi Media Sosial Untuk Pemilih Pemula. Jurnal Pengabdian Kepada Masyarakat, 2(9), 776-779. Retrieved from http:/ / journal.unpad.ac.id/pkm/article/view/20346

Husna, F., \& Novita, T. R. (2019). Antisipasi Hoax Bagi Pemilih Pemula Dalam Pemilihan Presiden Tahun 2019. Prosiding Seminar Nasional Hasil Pengabdian, 2(1), 488-494. Retrieved from http://e-prosiding.umnaw.ac.id/index.php/pengabdian/article/ download/161/166

Juwandi, R., Nurwahid, Y., Lestari, A., Sultan, U., \& Tirtayasa, A. (2019). Media Sosial Sebagai Sarana Pendidikan Politik Untuk. 2(1), 369-378.

Michela Arnaboldi, J.-F. C. (2016). Social Media And Business: We've Been Asking The Wrong Question. 1(1), 1-28.

Moleong, L. (2013). Metodologi Penelitian Kualitatif (ketigapuluh). Bandung: PT. Remaja Rosdakarya. 
Munandar, H., \& Suherman, M. (2016). Aktivitas Komunikasi Pemerintahan Ridwan Kamil di Media sosial. Jurnal Hubungan Masyarakat, 2(1), 423-430. Retrieved from http:/ / karyailmiah.unisba.ac.id/index.php/humas/article/viewFile/3270/pdf

Panjaitan, P., \& Prasetya, A. (2017). Pengaruh Social Media Terhadap Produktivitas Kerja Generasi Millenial (Studi Pada Karyawan PT. Angkasa Pura I Cabang Bandara Internasional Juanda). Jurnal Administrasi Bisnis S1 Universitas Brawijaya, 48(1), 136238. Putri, W. S. R., Nurwati, N., \& S., M. B. (2016). Pengaruh Media Sosial Terhadap Perilaku Remaja. Prosiding Penelitian Dan Pengabdian Kepada Masyarakat, 3(1). https://doi.org/ 10.24198/jppm.v3i1.13625

Rachmandani, R. E., Purnomo, E. P., \& Kasiwi, A. N. (2020). The Electability Level of PDI-P on Social Media of Instagram. Mimbar/ : Jurnal Sosial Dan Pembangunan, 36(2), 271-279. https:// doi.org/10.29313/mimbar.v36i2.5457

Rahadi, D. R. (2017). Perilaku Pengguna Dan Informasi Hoax Di Media Sosial. Jurnal Manajemen Dan Kewirausahaan, 5(1), 58-70. https://doi.org/10.26905/jmdk.v5i1.1342 Rahmat, A. F., \& Purnomo, E. P. (2020). Twitter Media Platform to Set-Up Political Branding: Analyzing @Kiyai_Marufamin in 2019 Presidential Election Campaign. Nyimak: Journal of Communication, 4(1), 73. https://doi.org/10.31000/ nyimak.v4i1.2268

Rohim, M., \& Wardana, A. (2019). Analisis Politik Milenial/ : Persepsi Siswa SMA Terhadap Dinamika Politik Pada Pemilu 2019 di Indonesia. JIP (Jurnal Ilmu Pemerintahan)/ : Kajian Ilmu Pemerintahan Dan Politik Daerah, 4(1), 47-63. https:// doi.org/10.24905/jip.4.1.2019.47-63

Setiawan, H., \& Santoso, P. (2013). Model Optimalisasi Peluang Pemanfaatan Media Jejaring Sosial dalam Implementasi E-Governance di Indonesia. Jurnal Informatika. UPN "Veteran" Yogyakarta., 2013(semnasIF), 147-154.

Setyaningsih, P. N., Suadnya, I. W., \& Fajarica, S. D. (2020). Manajemen Konten Media Sosial Instagram pada BKKBN Provinsi NTB sebagai Strategi Humas dalam Membangun Brand Awareness. Journal Of Media and Communication Science, 3(1), 111.

Soliha, S. F. (2015). Tingkat Ketergantungan Pengguna Media Sosial Dan Kecemasan Sosial. Interaksi: Jurnal Ilmu Komunikasi, 4(1), 1-10. https:// doi.org/10.14710/ interaksi.4.1.1-10

Strandberg, K. (2013). A social media revolution or just a case of history repeating itself? The use of social media in the 2011 Finnish parliamentary elections. New Media $\mathcal{E}$ Society, 15(8), 1329-1347. https:// doi.org/10.1177/1461444812470612

Susanto, E. H. (2017). Media Sosial Sebagai Pendukung Jaringan Komunikasi Politik. Jurnal ASPIKOM, 3(3), 379. https://doi.org/10.24329/aspikom.v3i3.123 
Tassel, J. Van, \& Poe-Howfield, L. (2010). Summary for Policymakers. In Intergovernmental Panel on Climate Change (Ed.), Climate Change 2013 - The Physical Science Basis (pp. 1-30). https:// doi.org/10.1017/CBO9781107415324.004

Yunus, N. R. (2015). Kmp Versus Kih; Implikasi Ketatanegaraan Perseteruan Dua Kubu Dalam Dimensi Etika Politik. (95).

\section{ACKNOWLEDGMENT}

I would like to express thanks for the blessings of Allah SWT who have given us that I cannot count each one of which,that cannot be cashed in or assessed with material value. Should that of healthy favors that are given are counted with the material then it will be difficult for us to count. Therefore we are very grateful for what was given to us for his blessing and health. Not forgetting also salawat and salam to our lord Prophet Muhammad, his family, his sahabaat and his followers, that we may be included in it.

The author would like to thank all those who have provided support to the author, so that the author can finalize this paper. Our first remarks were delivered to Dr. EkoPriyo Purnomo, and Mrs. Aulia Rahmawati, M.IP as the Supervising Lecturer, as on their sidelines, they still had the time to provide direction, guidance, advice, support to us for the shortcomings in writing this paper. 